\title{
Dalit Movement in Karnataka: Current Challenges and Intersectional Aspects
}

\author{
Ambuja Kumar Tripathy \\ University of Delhi, New Delhi, India \\ Email: ambujatripathy@gmail.com
}

\begin{abstract}
Received: 04 Dec 2021; Received in revised form: 22 Jan 2022; Accepted: 04 Feb 2022
(C2022 The Author(s). Published by TheShillonga. This is an open access article under the CC BY license

(https://creativecommons.org/licenses/by/4.0/)
\end{abstract}

\begin{abstract}
This paper, based on the findings of a research project, draws on secondary literature along with field interviews in order to discuss challenges for and intersectional aspects of the Dalit movement in contemporary Karnataka. Dalit movement in contemporary Karnataka is characterized by increasing internal heterogeneity, complexity, and intersectionality. On the one hand, Dalit movement has to face up the challenge of reorganizing itself by overcoming the internal conflicts and contradictions. The issues of the left and the right or Madigas and Holeyas, shifting with regional specificities, has divided Dalit politics. This division is sharper on the issue of reservation. There has been a consolidation of the sub-caste identity within the larger Dalit politics. Also, Dalit politics is internally split with mushrooming of different Dalit Sangharsh Samiti (DSS). On the other hand, women's participation in Dalit movement of the state is very discouraging. This also is one of the reasons for weakening of the Dalit movement. The movement leadership is increasingly realizing that it has been unable to address the intersectionality between caste and gender. Based on the new realization, the movement has progressively shifted its focus from difference to radical interrelatedness.
\end{abstract}

Keywords — Dalit feminism, Dalit Sangharsh Samiti, Devdasi, Holeyas, interrelatedness, Madigas.

\section{INTRODUCTION}

Dalit movement in Karnataka, emerging in the early 1970s, is a classic case of a successful social movement in India. This movement for self-dignity has had a farreaching impact on the Dalits in the state of Karnataka. 'It played a decisive role', Yadav notes, 'in awakening the Dalits in Karnataka. But it also shook the rigid, irresponsible Hindu conscience... It really hailed a new era of hope for Dalits in Karnataka' (Yadav cited in Davidappa and Shivanna 2012: 1). The impact of Karnataka's Dalit movement can be seen in other parts of the country as well. In fact, Davidappa and Shivanna rightly observe, 'the movement ushered in a new vision of civil rights across India' (2012: 1). Central to Karnataka's Dalit movement is Dalit Sangharsh Samiti (DSS) (Dalit Struggle Committee). And, over the years, 'the DSS went on to become the organizationally strongest and long lasting Dalit movement in the country' (Omvedt 1994: 337). Nevertheless, the DSS is grappling with several critical issues currently. And, its nature of response would determine the future course of the Dalit movement in Karnataka. This paper makes an attempt to engage with the challenges and the intersectional aspects of the Dalit movement in Karnataka in the contemporary times.

The article is based on the findings of a research project funded by the Institute for Social and Economic Change (ISEC), Bengaluru. The project was completed in 2020 and the final project report was submitted in 2021. It first provides literature review in brief and indicates the methodology used. It offers then a discussion of the historical trajectory of the Dalit movement in Karnataka and the factors responsible for emergence of the DSS. The following section takes up the major interventions of the DSS since its genesis. The paper then discusses the emergence of internal complexity in the DSS and the subsequent challenges for the Dalit movement in Karnataka. It analyses the significance of the question of intersection of caste and gender for the DSS and the movement in general. The concluding section underline the emerging signs pertaining to revitalization of the DSS in recent times. 


\section{LITERATURE REVIEW AND METHODOLOGY}

Let us see now which aspects of intersectionality have informed this paper. Intersectionality focuses on the simultaneous and interactivity of social identity structures such as race, gender, class, sexual orientation, and caste in the experiences of privilege and oppression. It was 'introduced in the late 1980 s as a heuristic term to focus attention on the vexed dynamics of difference and the solidarities of sameness in the context of antidiscrimination and social movement politics' (Cho, Crenshaw and McCall 2013: 787). Crenshaw (1991: 1244) coined intersectionality to describe 'the various ways race and gender interact to shape the multiple dimensions of black women's employment experiences'. Crenshaw's (1989) "Demarginalizing the Intersection of Race and Sex: A Black Feminist Critique of Antidiscrimination Doctrine, Feminist Theory and Antiracist Politics" was an attempt to correct the singleaxis frameworks within feminist and antiracist discourses. Since then 'as intersectionality has emerged in a number of discursive spaces, the projects and debates that have accompanied its travel have converged into a burgeoning field of intersectional studies' (Cho, Crenshaw and McCall 2013: 785). Intersectionality recognizes various social identities that interact to form unique meanings and complex experiences within and between groups in society' (Hankivsky and Cormier 2011: 217). These need to be understood with a reference to, what Collins calls (1990), "the matrix of domination"- multiple systems of power and domination- changing temporally and spatially and in varying institutional settings. While intersectionality guides us to see how individuals are multiply vulnerable, at the same time it informs us that individuals 'under certain circumstances, also make use of the privileged aspects of their identity' (Lutz 2015: 42). Thus, it can be said that individuals are nodes of convergence for multiple, cross-cutting axes of subordination. Frequently disadvantaged along some axes and simultaneously advantaged along others' (Fraser 2003: 57).

Intersectionality is now well established as a theoretical framework, and it is widely used in gender studies, education, sociology, social work, anthropology, psychology, law, political science, and literary studies. The concept is considered as 'a heuristic device or a method that is particularly helpful in detecting the overlapping and co-construction of visible and, at first sight, invisible strands of inequity' (Lutz 2015: 39). Intersectionality is considered as an important research paradigm (Hancock 2007) and a primary analytic tool for theorizing identity and oppression (Nash 2008). Further, intersectionality is considered as a theory offering new potential and perspectives for the connectivity of a broad range of social science scholars' approaches (Davis 2008), and as a buzzword (Davis 2011). Walgenbach (2010) regards intersectionality as a new paradigm for the scientific community in that it offers a set of terms, theoretical interventions, premises, problem definitions, and suggested solutions. Similarly, Klinger and Knapp (2003) point out the potential of intersectionality for building of grand theory while expressing some concerns.

Intersectionality studies, according to Cho, Crenshaw and McCall, can be said to represent three loosely defined sets of engagements (2013: 785-786). First, studies that apply intersectionality to different context-specific inquiries. Interaction of race and gender with class in the labour market in different ways is a good example. Second, the approach involves discursive inquiries of intersectionality as a theoretical and methodological paradigm. 'It considers what intersectionality includes, excludes, or enables and whether intersectionality's contextual articulations call either for further development or for disavowal and replacement' (Cho, Crenshaw and McCall 2013: 785). Third, political interventions or praxis forms a crucial aspect of intersectional theory and critique. Praxis includes a range of efforts such as movements demanding economic justice, legal and policy advocacy to address gender and racial discrimination and movements initiated by the state for abolition of prisons, immigration restrictions, and so on. Coming to levels of analysis for intersectionality now, Floya Anthias (1998) suggests a multi-level analysis that consists of four levels, namely, the level of experience of discrimination, the level of actors and their praxis, the level of institutional regimes, and the level of representation involving symbolic as well as discursive. This takes us to intersectionality as methodology.

While intersectionality is considered as a concept, a theory, and an analytical tool for analysis, it is also considered as a method. However, lack of strong intersectionality methodology is a major challenge for the use of intersectionality as a theoretical framework. Hancock states, 'one area of research that remains underexplored within intersectionality is the development of research designs and methods that can capture effectively all of the tenets of intersectionality theory' (2007: 47). In this connection, Kathy Davis (2014) argues that gender, which is central to feminist research, should not be considered as a standalone category. Rather, gender is related to other differences and mutually constituted by such differences. At this point, Mary Matsuda's method 
of 'the other question' as “interconnection of all forms of subordination" (1991) becomes so relevant. Matsuda explains: "When I see something that looks racist, I ask "Where is the patriarchy in this?" When I see something sexist, I ask "Where is the heterosexism in this?" When I see something that looks homophobic, I ask "Where are the class interests in this?" (1991: p. 1189). Matsuda thus suggests that multiple differences need to be considered instead of exclusively focusing on one category. "The other question" in the Indian context can be extended to include caste and tribe as well. McCall (2005) discusses three distinct intersectional methodologies. The first approach is 'anticategorical complexity', which is premised on the assumption that categories such as race and gender are too simplistic to capture the complexity of lived experience (2005: 1776). The second approach is 'intracategorical complexity' seeks to reveal the complexity of lived experience within marginalized intersectional identities such as black women. The third approach is 'intercategorical complexity' that 'provisionally adopt existing analytical categories to document relationships of inequality among social groups and changing configurations of inequality along multiple and conflicting dimensions' (2005: 1773).

Taking these arguments further, Lutz (2015) delineates three levels of intersectional analysis. First, 'partiality' has to be taken into account. Partiality stands for the 'differences in situatedness between the two people involved in the interview'. Differences can be seen in terms of gender, class, race, ethnicity, nationality, and so on that have an important role in the concept of self. Lutz argues, 'it is very likely that the interviewee her / himself uses intersectionality in the construction of her / his lifestory as much as the interviewer does in her / his analysis' (2015: 41). Thus, intersectionality has to be applied to the narrator as well as the analyst. Second, one has to carefully analyse the use of identity category by the interviewees in their narration. Lutz states, 'the identity category that is used in the first place or most frequently is not necessarily the most important one. Rather it may be that that is the identity aspect that is repeatedly attacked and therefore defended' (2015: 41). The third level of intersectional analysis is concerning power relations. Power relations are not fixed, rather they vary based on context, locality and point in time (Lutz and Davis 2005). Using the term "doing intersectionality", Lutz aims at exploring "how individuals creatively draw on various aspects of their multiple identities as a resource to gain control over their lives' (2015: 41).

Intersectionality also has the potential to work as a coalition-building tool for those in the common pursuit of social justice (Miller et al. 2007; Cole 2008; Hanvisky and Cormier 2011). It can identify, in Cole's words, 'spaces for shared mobilizations' (2008: 447). Such coalition-building can be worked out among individuals or movements. Intersectionality 'can also be a powerful tool to build more effective alliances between movements to make them more effective at organizing for social change' (Roberts and Jesudason (2013: 313). Even Crenshaw argued that the single-axis frameworks, by treating struggles as singular issues, 'undermine potential collective action' and intersectionality provides scope to create 'some basis for unifying activity' (1989: 167).

Roberts and Jesudason (2013) take this argument further and highlight the exciting paradox of intersectionality: 'attending to categorical differences enhances the potential to build coalitions between movements and makes them more effective at organizing for social change' (315). It has three major implications according to them. First, this does not mean transcending differences. Differences need to be acknowledged, explored and analyzed but intersectionality should not create "homogeneous "safe spaces"' (Cole 2008) where some are isolated from others on the basis of separate identities. Second, intersectionality enables active engagement among people with differing identities, on the basis of their commonalities, for political activism. Keating discusses the tool of 'making connections through differences' in order to 'forge commonalities without assuming that their experiences, histories, ideas, or traits are identical with those of the others' (2009: 85). Third, discussion of such commonalities suggests that oppressive structures are related. This leads to the understanding that struggles are related, hence alliances and coalitions are required to face the challenge of 'matrix of domination'. Such alliances 'do not require anyone to choose one's oppression over another nor to sacrifice some needs over others' (Russo 2009: 309,315). Thus, Roberts and Jesudason emphasize 'radical interrelatedness' along with differences in intersectional framework and argue, 'the radical potential for intersectionality lies in moving beyond its recognition of difference to build political coalitions based on the recognition of connections among systems of oppression as well as on a shared vision of social justice' (2013: 316). Further, Laperriere and Lepinard (2016) argue that focus on intersectionality sheds light on the tensions inherent in the processes by which organizations construct collective identities, formulate political demands, manage internal conflicts, and build alliances. While being influenced by these ideas, the paper is familiar about the debate over intersectionality (Ferguson 2000; Zack 2005; Nash 2008, 2009; Menon 2015). 
This paper is based on the qualitative data collected from primary as well as secondary sources. First of all, it uses secondary data obtained from various sources- books, journals, personal sources, newspapers, blogs, and so on. In this connection, the availability of rich resources in the ISEC library and Bangalore University library is worth mentioning. Additionally, the paper uses primary data collected through direct personal interviews. I interviewed some prominent Dalit scholars, activists, and political leaders based in Bengaluru and other parts of Karnataka in early 2020. In this process of primary data collection, I used semi-structured questionnaires and observations. Whenever required, I translated the responses in Kannada into English with the help of trained translators. After having discussed methodology, I turn to a brief discussion of the genesis and evolution of the Dalit movement in Karnataka in the following section.

\section{A HISTORICAL ACCOUNT OF THE DALIT MOVEMENT IN KARNATAKA}

The Dalit movement emerged in Karnataka in the 1970s. However, seen from a historical perspective the roots of the movement go back to the earlier times in Karnataka and other southern states when challenges were made to the dominant Brahminic ideas under Buddhist influence. 'Sharana Sanskriti, drawn from the Buddhist cultural movement,' argues Yadav, 'operated as the linking line of articulation and assertion for non-Brahmin movements in these states' (2019: 53). In this regard, the earliest known personality is Basaveshwara who is considered as the founder of the Lingayat religion. He was a major advocate of the values of the Sharana tradition. Based on the Buddhist ethical values, he organized people in the state against inequality and oppression associated with the priestly tradition in Brahminism. It was found quite appealing by the untouchables. Basaveshwara's movement had the objective 'to establish a right relationship between man and man, God and religion such that universal values of love, compassion and brotherhood became fundamentals of life' (Yadav 1998: 108). Basaveshwara revived Buddhism in the form of Lingayatism that challenged the oppressive aspects of Hinduism. Yadav notes, 'indeed, the essence of the struggle between Brahminism and Buddhism is the driving spirit of the Dalit movement in Karnataka' (2019: 55). Thus, Buddha and Basaveshwara (along with Ambedkar) have become the ideological symbols for the Dalit movement in Karnataka.

Then, there was non-Brahmin and Dalit awakening and mobilization in Mysore state during the colonial period. It is important to note Dalit consciousness in the kingdom of
Mysore during Tipu Sultan's rule. Kudmul Ranga Rao, a social reformer in the second half of the $19^{\text {th }}$ century, played a significant role with respect to eradication of untouchability in South Kanara region. He is considered as "one of the pioneers of depressed classes movements in Southern India for providing education, better housing,employment and empowering the depressed classes socially by guarding them against exploitation by upper classes" (Ushaprabha 2013: 50). Several nonBrahmin castes organized themselves for self-assertion in the late nineteenth and early twentieth centuries under the influence of earlier Basaveshwara's philosophy, and reform movements such as Brahmo Samaj, Arya Samaj and Ramakrishna Mission. Yadav argues, 'castes like the Lingayats rejected Hindu framework and attempted to attain social prestige and status within the Lingayat framework' (1998: 109). The Lingayats and Vokkaligas set up their caste associations and confronted the Brahminic domination in the public services. In 1917, Praja Mitra Mandali was founded by C. R. Reddy following the ideas of Jyotiba Phule. This was an attempt by Reddy to unite all the non-Brahmin groups and, thus, strengthen the movement against Brahmin domination.

Ambedkar's ideas and initiatives had the strongest impact on the rise of the Dalit movement in Karnataka. Ambedkar's influence was strongly felt in the Hyderabad and Bombay regions of the state. Ambedkar organized the first convention of untouchables in 1920 in Mangaon, which is very close to the Belgaum district of Karnataka. He was invited to address several gatherings of the Dalits in Belgaum. Ambedkar's Bahishkrit Hitkarini Sabha, founded in 1924, set up hostels for the students of the depressed classes in Sholapur district of Maharashtra and Belgaum. He inaugurated the Machagar Mahasangh in Dharwad in Karnataka in 1927 through which Chamars were mobilized. Ambedkar's influence was so strong that 'when he rose to the national fame', writes Yadav, even the Princely state of Mysore, which had a Gandhian leaning, changed its attitude towards Ambedkar' (2019: 58). He received land from the Prince of Mysore to start a Buddhist monastery and educational institutions. Further, 'the conversion to Buddhism took place at Kolar Gold Field even before the historic mass conversion to Buddhism at Nagpur in 1956' (Khirsagar quoted in Yadav 2019: 58). Ambedkar's contemporaries organized selfrespect movement for the Dalits in Belgaum district of northern Karnataka. The movement was quite a radical one focusing on identity aspect of the Dalits and appealing them for change of name as well.

After Ambedkar, three major developments took place that have significant bearing for the Dalit movement in Karnataka (Yadav 2019: 59). First, Shyam Sunder, a 
strong follower of Ambedkar's ideas, organized Dalits especially in southern Karnataka. Sunder was a law graduate from Hyderabad Karnataka region, external affairs Minister in the Nizam government, and first Dalit Member of Legislative Assembly (MLA) from his area. He set up Bhim Sena in 1968 and set forth four important demands: 'surrender of $25 \%$ of villages in every taluk, a separate electorate, a separate Scheduled Caste University in each state and a strong political organization for untouchables' (Shyam Sunder quoted in Yadav 2019: 59). He was extremely radical in his approach, and spoke vociferously on caste atrocities and the land issue. He demanded hostels and scholarship for both Dalit as well as tribal students. He was well aware about discrimination and marginalization faced by both Dalit and tribal students.

The second development is related to another strong Ambedkarite, B. Basavalingappa. Unlike the militancy of the Bhim Sena, Basavalingappa worked towards revival of Buddhism as envisaged by Ambedkar. And, the third development has to do with the formation of the DSS in the early 1970s. During the Chief Ministership of Devraj Urs, three Dalit Cabinet Ministers - Basavalingappa, Rachaiah and Ranganath 'who had the courage to give voice to the Dalit communities and they ably used the government machinery to tackle the rising atrocities in the villages against the Dalits. It was this support that made progressive intellectuals come together and dream of a platform like the DSS' (C Muniappa quoted in Davidappa and Shivanna 2012: 4). It was at this juncture that Basavalingappa criticized the entire Kannada literature as Boosa (cattle fodder) having nothing for the Dalits, which led to bitter controversy and strong uproar in the state. This incident acted as the triggering factor for the formation of the DSS.

Before we turn to the interventions of the DSS over last few decades, let us have a look at the nature of caste conflict in rural areas of Karnataka. Muzzafar Assadi argues that the changing nature of caste conflict or contradiction has to be seen in three major phases (1997). In the pre-1970 period, rural conflict was between upper castes and dominant castes. Then the second phase began when 'dominant castes occupied the space left by the upper castes; leading to new forms of contradictions between dalits and dominant castes (Assadi 1997: 2017). The next shift started towards the end of 1980s that witnessed conflict between Dalits and Scheduled Tribes (STs). In this context, Assadi cites the example of attack on the Dalits by the Nayaka community in Udbhur village near Mysore on July 8, 1997.

\section{MAJOR INTERVENTIONS BY THE DSS}

After formation in the 1970s, the DSS has made a significant impact on the Dalits in Karnataka. Yadav states, 'indeed the DSS was a revolutionary beginning. DSS founded itself on the concept of attaining an entity of wholeness where art, culture, science and activism operate together, with the spirit of both reason and emotion to wage war on the established notions of exploitative relationships functioning int he society of Karnataka' (2019: 60). Under the banner of the DSS, a united front of Dalit artists, writers, poets, thinkers, and activists was created. Innovative methods and techniques such as workshops, discourses, cultural programs, and cadre camps were used by the DSS to educate and organize people. Major rallies and protest events were organized in different parts of the state. Thus, within a decade DSS could make its impact felt across the state.

DSS took up several critical issues affecting the Dalits. First of all, it was the practice of untouchability and atrocities on the Dalits. Soon after the formation of the DSS, a violent incident took place in the district of Kolar in 1974. Killing of a Dalit student by people from the Vokkaliga caste led to stir among the Dalit youth and, later, Dalit masses. A district unit of the DSS was set up in Kolar. Another violent incident took place in 1978 with regard to the electoral contest by a Dalit candidate with a Vokkaliga candidate in Chinthamani Assembly constituency. People from the dominant caste forcible entered the locality of the Dalit candidate and resorted to violence. Agitations by the DSS resulted in arrest of the culprits. Similarly, the DSS had active intervention in the violence against Dalits by the dominant caste Vokkaligas in Billandla Halli village in late 90s and Kamblapalli village in 2000.

Second, the DSS took up the issue of grant of land in several villages across Karnataka from 1975 onwards. In fact, 'each district unit of the DSS planned the land struggle even though it did not achieve much. The Sidlipura land struggle was the first of its sort and was followed by similar struggles in Chandagodu, Bidrekavalu, Kalasankoppa and others.' (Yadav 2019: 61). DSS looked into the auctioning of land of a Dalit through fraudulent means in Kolar district in 1978. A list of demands was presented to the state government and distributed among the people by the DSS. Demands included implementation of the Land Reform Act, 1978 with immediate effect, immediate settlement of all the pending cases of the Dalits in the taluk courts by the district collector, grant of minimum of five acres of land to all the landless Dalits in Kolar district, and others. Then comes land struggle in Nagasandra village in the same 
district in the early 80s. A strong agitation was led by the DSS with the slogan "Not Toddy but Education". It can be said that "even today the land struggle has remained an important issue tot eh fragmented DSS units in the state. Therefore, the emergence of DSS raised 'the aspirations for self-determination of the toiling lower caste communities across the state of Karnataka' (Davidappa and Shivanna 2012;8). This takes us to the next point.

Third, closely associated with the earlier two types of interventions is the self-respect aspect of the Dalits. In its caste as well as land struggles, DSS had self-assertion and self respect of the Dalits uppermost in mind. DSS, Davidappa and Shivanna note, 'used handbills, posters, rallies, Dharnas, picketing government offices, marches, Padayathras, cadre building trainings, workshops, conventions, street theatre, songs of awareness building and others to drive home the single agenda that untouchability is un-constitutional and "lower castes" too had equal rights and opportunities to lead dignified life' (2012:10). The slogan of the DSS, "educate, organize, and agitate", aimed at securing life with dignity and selfconfidence for Dalit community. In this light, the huge gathering of Dalits in Bengaluru on April 14, 1986 (Ambedkar Jayanti Day) for the launch of the 'SelfRespect' movement needs to be seen. Constitution and flag for DSS were released during the Swabhiman Samavesh (self-respect conclave). In this context, it becomes important to see the ideological influence over the DSS coming from Buddha, Basaveshwara, Ambedkar, Lohia, and Periyar. While local cultural figures were also used as symbols, Ambedkar remained the central symbol for the DSS while organizing the Dalits. And Ambedkar's ideas on restoring dignity of the Dalits were frequently invoked by the DSS in its struggles.

Finally, let us look at the ways the DSS attempted to grapple with the intersection between caste and gender. The issue of Devadasi was taken up by the DSS. Devadasi was a religious practice in which young Dalit women remained devoted throughout their life to Goddess Yellamma. They were sexually harassed by the rich upper caste men in their villages. DSS politicized this issue and organized a huge procession in Soudatti, where Yellama's temple is located, in 1985. DSS also raised the issue of traditional practice of nude worship of Goddess Yellamma. Then, the matter of violence against Dalit women caught the attention of the DSS. One of the earliest cases of caste based gender violence was the gang rape and murder of Chinnamma by Vokkaligas in Doddi Halli village in late 1970s. DSS organized the Dalits and led agitations against these barbaric acts of the dominant caste men. In 1979, another such unfortunate incident took place. Anasuyamma, a widow aged nineteen, was gang raped by the Vokkaliga caste men in Hunasi Kote village in Malur Taluk. DSS, beginning with the Taluk unit, made active intervention. Police complaint was lodged, two day camp was organised, and lamp of Anasuyamma's father was taken by the DSS cadres from his grave in the village to Karnataka Legislative Assembly in Bengaluru by padayathra. In the padayathra, DSS used several symbols and spectacles such as singing songs, performing street theatre and distributing pamphlets to reach out the wider public and mass media. Davidappa and Shivanna describe: 'the three day protest march from Hunasi Kote to Bangalore and the latti-charge finally resulted in wide awakening of the lower castes across the state... The song that was written in the name of Anasuyamma is sung by the DSS cadre even today' (2012: 8). Further, when the heinous act of parading a Dalit woman naked was done on the streets in Bidaroli village of Belgaum district in 1986, DSS organized a massive rally in Bengaluru condemning such incidents. DSS got the culprits punished as well through the follow up measures. The irony is that around this time, the DSS started facing crises that we will discuss in the next section.

\section{COMPLEXITY, CHALLENGES, AND INTERSECTIONALITY}

It was the year 1986 when a new critical turn came in the trajectory of the DSS. It began with the issue of leadership of the DSS. Yadav explains: 'till 1986 the DSS functioned with full measure of its completeness... There was perfect harmony, from top to the bottom level, between all the wings of DSS. The leadership so far was natural and grounded on common consent' (2019: 65). B. Krishnappa was the DSS convener till 1986. In the DSS meeting in Dharwad in 1986, a decision was taken that DSS conveners would be democratically elected. It was decided that state convener would be elected by the district conveners. A prominent Kannada personality Devanoor Mahadev was elected as the state convener. In the same meeting, the matter of the DSS symbol was also discussed that resulted in a bitter controversy without any final agreement. These developments point to the appearance of internal divisions and factions in DSS. Widespread scepticism grew that the era of collective and spontaneous leadership in DSS got over with election and acute disagreement.

Internal divisions in the DSS after 1986 indicate five major factions. One faction was led by Devanoor Mahadev, the new state convener of the DSS. Second DSS faction was that of the Gandhians. Socialists later joined this faction. Third major faction was constituted by 
the Marxists. There were ideological clashes between the Gandhians and Marxists. During these ideological clashes, fourth faction emerged consisting of the Ambedkarites. There was a clear influence of Maharashtra Dalit movement and Marathi writers on this group of Ambedkarites. In this connection, Dalit Students Federation in Kolar needs to be seen. Naxalites on the Andhra side can be considered as the fifth group. Gandhians and socialists within the DSS fold came together due to Prof Ananthamurthy's key mediating role. They remained in contact with the state government led by Ramakrishna Hegde during that time.

The repercussions of these events were felt in the following years. The democratically elected leadership could not keep the DSS united. Some eminent persons moved away from the DSS (interview with Prof Manohar Yadav in Bengaluru on January 27-28, 2020, Prof Yadav himself was actively associated with the DSS till 1986). A clear split in the DSS became explicit with the setting up of another DSS in the state. The split was seen even at the smallest level of hamlets. Gradually, further splits took place and many more DSS were set up. Thus, it became difficult for people to figure out the original DSS. Regional diversities, earlier accommodated within the structure of the DSS, took the form of new organizations. Organizations in northern part of the state are good instances in this regard. Caste organizations like the Machagar Mahasangh got revived as separate entities. Faction groups, instead of building up of the organization, started pursuing quick benefits by developing close connection with political parties, administrative and police wings of the state. Similarly, cadres also became self-seeking in the absence of unified visionary leadership. DSS further got weakened with clear internal division based on sub-caste identity especially on the issue of reservation. It was between Madigas (left-hand Dalits) and Holeyas (right-hand Dalits). Madigas organized several demonstrations demanding separate quota in reservations in employment.

A fundamental weakness of the DSS was the lack of inadequate attention given to the intersection of caste and gender. In general, Gopal Guru aptly points out the patriarchal nature of Dalit movements since they reproduce the mechanisms against Dalit women that 'the upper caste men use against women' (1995). Although the issues of Devadasi practice and gender violence were taken up, DSS could not systematically and strategically address the dynamics of Dalit women causing the situation of double injustice for them. This could be seen as a major enabling condition for the emergence of 'Dalit feminism' and Dalit feminist writings in contemporary Karnataka. Further, the lack of women's leadership in the DSS adversely affected women's participation in its activities. This gradually alienated the Dalit women from the DSS.

In this connection, it is useful to note that increasing attention given to gender dynamics by several Dalit leaders in the movement in recent times is a welcome step. However, the attention needs to be more systematic and sustained. At the same time, it is important to note the limitations of this project to explore this matter further. For instance, I think asking and articulating more nuanced intersectional questions in further conversations with movement participants would have given me stronger clue about enabling (or disabling) conditions for the emergence of Dalit feminism. Also, a closer engagement with the role played by women participants in C. R. Reddy initiated Praja Mitra Mandali and Savitri Bai's interventions would get some pertinent insights on the question pertaining to gendered role models within the Dalit movement. Furthermore, while discussing mobilizations by the DSS around the issue of Devadasi, I could not interview female children of Devadasis. In addition, I did not get a chance to interact with women's organizations that strive on both fronts: (i) fighting for Devadasi women in their day-to-day struggle against the structural and gender violence and (ii) fighting against the exploitation of Devadasi families by mining mafia in districts such as Ballari. An interview with women civil society actors such as Bhagyalaxmi of Sakhi Trust in Hospete would have brought further insights on intersectionality questions. The time period of the project did not allow me to conduct these interviews. The research limitations, identified above, point the way forward for further research. Please see in the box a brief summary of my interview with Dr Venkataswamy, currently president of the Republican Party of India (RPI), Karnataka.

\section{CONCLUSIONS}

To sum up, the Dalit movement in Karnataka could not provide sufficient attention to intersection of caste and gender in the past. It certainly took up the issues such as the practice of Devadasi and violence against Dalit women by the dominant caste men. The movement even succeeded to a great extent in this regard. The movement could raise the consciousness among Dalit men and women about their identity. However, the movement is found having several weaknesses seen from the perspective of the intersectionality. First, while interequality between Dalits and upper or dominant caste was highlighted by the movement, intra-equality between Dalit men and Dalit women was not taken up seriously on 
its agenda. Second, resulting from the first point, the movement could not articulate a systematic strategy to deal with the gender aspect of caste or double oppression. Thus, the movement neglected the issues that Dalit women face in their day-to-day life. Finally, leadership of the movement remained gendered. Dalit movement could not conceive of recruiting and training women for leadership roles on a proper systematic basis. Importantly, several respondents acknowledged the point of intersectionality that intersecting identities need due consideration within the movement. It indicates that there is a greater appreciation of intersectionalist values now within the movement. This is not to downplay the role of diverse activities undertaken by the movement or the DSS in the state so far.

\section{Interview of Dr Venkataswamy}

This interview was conducted on February 6, 2020 at Dr Venkataswamy's residence in Bengaluru. He has been actively associated with the Dalit movement in the state. He first offered a historical perspective on his association with the Dalit movement and DSS. In the early 70s, literary Dalit figures emerged in Shimoga, Mysuru and Bengaluru universities after the Boosa episode (seen earlier) and spoke on the Dalit issues. Basavalingappa and Sidalingaya were the most prominent persons associated with the Dalit movement at this stage. Dalit artists-writers forum was founded. There were caste based clashes and Dalit students' protests. Venkataswamy himself led the protest of Dalit students in Kolar district. These were some of the most important forces that led to the formation of state level DSS in 1975. In the second meeting of DSS in Mysuru, modalities for the organization were worked out. B. Krishnappa became the president, and district branches of teh DSS were established. Venkataswamy became the first district convener of the DSS in Bengaluru. District units of the DSS actively took up the issue of Dalit atrocities in their respective areas. Venkataswamy was closely associated with the DSS until mid-1980s. After he left the DSS, he formed the Samata Sainik Dal.

Dr Venkataswamy throws light on his departure from the DSS. With regard to internal divisions in the DSS, Venkataswamy was associated with the group of Ambedkarites. He argues that while Gandhians and Marxists were in favour of sharing political power for making right policies for the Dalits, Ambedkarites and Naxalites were in favour of protest against the government since the government was unable to stop caste atrocities. The later groups challenged the ones supporting government. This led to the cornering of Venkataswamy by the government as he explained.

Then, a new chapter in Venkataswamy's trajectory began. A new group called DSS Coordination was started by Venkataswamy. He got in contact with Kansiram, President of Bahujan Samajwadi party (BSP). His support and closeness to Kanshiram resulted in clashes within the DSS Coordination. This group does not exist anymore. Venkataswamy recalls major activities in the late 80s and early 90s such as formation of Ambedkar Centenary Forum, organizing Bhim March involving cycle rally throughout Karnataka, distribution of literature on Ambedkar, and holding awareness programs. A major conference was organized in Cubbon Park in Bengaluru. Dalitostav (Dalit festival) was organized which was attended by around twenty five thousand people. At this juncture, Samata Sainik Dal was formed and Republican Party of India (RPI), Karnataka was set up. Dalit Organization Federation was created as a coordination group to propagate Ambedkar's ideas. Venkataswamy became President of the Federation. Dalit Organization Federation could bring twenty three DSS factions together on certain agendas. The most important demands include Dalit Chief Minister for the state, Prevention of Transfer of Certain lands (PTCL), and reservation in promotion in jobs. Venkataswamy states that RPI gives priority to Ambedkar's ideas and supports the Ambedkarites. It aims to rejuvenate the Buddhist movement in the state. He talked about a mega event planned for October 14, 2020 where ten lakh people would take oath in the Buddhist principles.

On the issue of intersection of caste and gender, Venkataswamy agrees that the DSS has not been able to give due attention to it even though it has taken up the issue of atrocities on Dalit women. Of late, he argues, Dalit women's leadership issue has also been taken up. Several Dalit women activists and leaders have emerged. In this connection, he states that a regional conference led by Muslim women in Belgaum would be organized on March 21, 2020. Further, a leadership motivation camp would be organized for Dalit men and women. Regarding anti-liquor struggle of women in the state, Venkataswamy contends that the RPI manifesto includes ban of liquor. Further, he states that the RPI manifesto supports the anti-mining struggles in the state. However, he stresses two points in this connection. First, his party would directly and strongly support people's movements if they make their presence felt at the state level and not just remain confined to the local level. Second, his party supports the anti-liquor and environmental struggles, but Dalit issues remain the topmost priority for his party. 
Furthermore, as noted earlier, there is the widespread concern about factionalism in the Dalit movement in the state. A major challenge for the DSS is to get rid of its internal weaknesses in order to effectively work for creating a more egalitarian system. Nevertheless, there are some positive signs of revitalization of the DSS in the recent times. 'Many of the split DSS groups have become redundant', observes Yadav, 'with no real following in the state. Hence are slowly becoming extinct. This has led to the expansion of truly passionate factions' (2019: 67). Among all the faction groups of the DSS, the most important one is known as the Ambedkarvad group led by Mavalli Shankar. This group has belief in Buddhist values and Ambedkarite methods as the criteria for its membership. It rejects the idea of separate reservations in employment on the basis of sub-caste identity. Two more major factions of the DSS are led by Indoodhar Honnappa and Muniappa. A few other prominent names currently associated with the Dalit movement in the state are Mohan Raj (Bhimvada), Venkataswamy (Republican Party of India) and Laxmi Narayan Nagavar. In recent times, the coming together of all the factions of DSS can be seen in certain contexts. One such instance is collective organization of a large-scale conversion of Dalits to Buddhism in 2003. Another good example is collective support to teaching English language from the first standard onwards in all Kannada primary schools of the state. The potential of these new developments to address the critical challenges and intersectionality that the Dalit movement in Karnataka is currently facing needs to be further explored. With all its strengths and research limitations, this paper hopefully would contribute to the movement studies and intersectionality studies.

\section{ACKNOWLEDGMENTS}

I am grateful to the Institute for Social and Economic Change (ISEC), Bengaluru for funding the research project. I would like to thank all the respondents, especially Prof Manohar Yadav and Dr Venkataswamy. My thanks to the anonymous reviewers of the project report and this paper.

\section{REFERENCES}

[1] Assadi, Muzaffar. (1997). Changing nature of caste conflict: Udbhur incident. Economic and Political Weekly. (9 August).

[2] Chang, R. S. and Culp, J. M. (2002). After intersectionality. University of Missouri-Kansas City Law Review. 71.
[3] Cho, S., Crenshaw, K. M., \& McCall, L. (2013). Toward a field of intersectionality studies: theory, applications, and praxis. Signs. 38 (4).

[4] Cole, Elizabeth. (2008). Coalitions as a model for intersectionality: From practice to theory. Sex Roles. 59.

[5] Collins, Patricia Hill. (2005). Black sexual politics. New York: Routledge.

[6] Crenshaw, K. (1989). Demarginalising the intersection of race and sex: A Black feminist critique of antidiscrimination doctrine, feminist theory and antiracist politics. University of Chicago Legal Forum.

[7] ------o (1991). Mapping the margins: intersectionality, identity politics, and violence against women of color. Stanford Law Review. 43 (6).

[8] Davidappa, Dominic and Shivanna. (2012). Emergence of the DSS in Karnataka: contesting society, state, and bureaucracy from below. Caste out of Development Project.

[9] Davis, Kathy. (2008). Intersectionality as buzzword: A sociology of science perspective on what makes a feminist theory successful. Feminist Theory. 9(1).

[10] Gopaldas, Ahir. (2013). Intersectionality 101. Journal of Public Policy \& Marketing. 32.

[11] Hankivsky, Olena and Cormier, Renee. (2011). Intersectionality and public policy: some lessons from existing models. Political Research Quarterly. 64 (1).

[12] Klinger, C. and Knapp, G. (2005). Achsen der ungleichheit - achsen der differenz. verhaltnisbestimmung von klasse, geschlecht, 'rasse'/ethnizitat. Transit. 29.

[13] Kwan, P. (1996). Jeffrey Dahmer and the cosynthesis of categories. Hastings Law Journal. 48.

[14] Laperriere, M. and Lepinard, E. (2016). Intersectionality as a tool for social movements: Strategies of inclusion and representation in the Quebecois women's movement. Politics (17 June).

[15] Lutz, Helma. (2015). Intersectionality as method. DiGeSt. Journal of Diversity and Gender Studies. 2 (1-2).

[16] Matsuda, M. (1991). Beside my sister, facing the enemy: Legal theory out of coalition. Stanford Law Review. 43(6).

[17] McCall, L. (2005). The complexity of intersectionality. Signs. 30 (3).

[18] Menon, Nivedita. (2015). Is feminism about 'women'? A critical view on intersectionality from India. Economic and Political Weekly. L (17) (25 April).

[19] Miller, V. L. et al. (2007). Making change happen 3: Power: concepts for revisioning power for justice, equality and peace. COMM-ORG Paper 13. Available at http://comm-org.wisc.edu/papers2007/miller.htm., last accessed on June 16, 2020.

[20] Nash, Jennifer C. (2008). Re-thinking intersectionality. Feminist Review. 89.

[21] Roberts, Dorothy and Jesudason, Sujatha. (2013). Movement intersectionality: the case of race, gender, disability, and genetic technologies. DU BOIS Review: Social Science Research on Race. 10 (2).

[22] Shah, Abhishek. Feminism and Intersectionality: Is Intersectionality a Useful Analytical Framework for Feminists in India. Available at 
https://www.epw.in/engage/discussion/intersectionalityuseful-analytical-framework, last accessed on November 15, 2020.

[23] Simien, Evelyn M. and Hancock, Ange-Marie. (2011). Mini-Symposium: Intersectionality research. Political Research Quarterly. 64 (1).

[24] Urbanek, D. (2009). Towards a processual intersectional policy analysis. Unpublished report for Quality in Gender+Equality Policies. Available at http://www.quing.eu/files/2009/inter_urbanek.doc, last accessed on November 12, 2019.

[25] Ushaprabha, D. (2013). Role of Kudmul Ranga Rao in empowerment Of Dalits in the undivided Dakshina Kannada district. Journal of Public Administration and Policy Research. 5(2). Available at https://pdfs.semanticscholar.org/c403/3a964f8d63f948fle9 e57b858d90ae284c7a.pdf, last accessed on February 2, 2022.

[26] Wilkinson, L. (2003). Advancing a perspective on the intersections of diversity: Challenges for research and social policy. Canadian Ethnic Studies. 35(3).

[27] Wing, A. K. (1990). Brief reflections toward a multiplicative theory and praxis of being. Berkeley Women's Law Journal. 6.

[28] Yadav, Manohar. (2019). Whither the Dalit movement in Karnataka? Its achievements and challenges. In M V Nadakarni (ed.). Socio-Economic Change and the BroadBasing Process in India. New Delhi: Routledge. 